http://revped.ise.ro

Print ISSN 0034-8678; Online ISSN: 2559 - 639X

\title{
INTERCOMPREHENSION IN THE FOREIGN LANGUAGE CLASS
}

INTERCOMPREHENSIUNEA ÎN PREDAREA LIMBILOR STRĂINE

\section{Andreea-Manuela COJOCARIU}

\author{
Journal of Pedagogy, 2017 (2), 27 - 40 \\ https://doi.org/10.26755/RevPed/2017.2/27
}

The online version of this article can be found at: http://revped.ise.ro/category/2017-en/

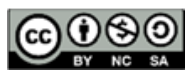

This work is licensed under the Creative Commons Attribution-NonCommercial-ShareAlike 4.0 International License. 94042, USA

Published by:

\section{INSTITUTUL DE ȘTIINTTE ALE EDUCAȚIEI}

http://www.ise.ro/

Further information about Revista de Pedagogie - Journal of Pedagogy can be found at:

Editorial Policy: http://revped.ise.ro/editorial-policy/

Author Guidelines: http://revped.ise.ro/the-writer-guide-2/ 


\title{
INTERCOMPREHENSION IN THE FOREIGN LANGUAGE CLASS
}

Andreea-Manuela COJOCARIU*

\begin{abstract}
The concept of intercomprehension is now part of the lexicon of the Didactics of Languages or of the vocabulary of those who reflect on teaching and learning foreign languages in the context of promoting the plurilingualism of European citizens. Intercomprehension is one of the current concerns although it has not yet really entered school and university institutions. It is in the state of experience, project or training and yet there is abundant material and intense reflection on this subject. Intercomprehension is considered practical worthy of being tried and for this reason there is a pedagogy and didactics of intercomprehension. My objective regarding intercomprehension is to investigate the interest, the possibilities and the modalities of a better awareness of the contact of languages in the classes of FFL (French as a Foreign Language).
\end{abstract}

Keywords: foreign languages; intercomprehension; plurilingualism.

\section{Rezumat}

Conceptul de intercomprehensiune este acum parte a lexicului Didacticii limbilor sau a limbajului celor care reflectează asupra predării şi învă ării limbilor străine în contextul promovării plurilingvismului cetă enilor europeni. Intercomprehensiunea este una dintre preocupările actuale, chiar dacă nu a intrat oficial în şcoli şi în universită i. Intercomprehensiunea este încă în stadiul de experiment, proiect sau formare şi totuşi există material bogat şi o preocupare didactică intensă cu privire la acest subiect. Acest concept are meritul de a incita la experimentare şi din acest motiv există o pedagogie şi o didactică a intercomprehensiunii. Obiectivul meu cu privire la acest subiect este acela de a explora interesul, posibilită ile şi modalită ile unei mai bune în elegeri a contactului limbilor în clasele de limbi străine şi în special a celor de limbă franceză.

Cuvinte-cheie: intercomprehensiune; limbi străine; plurilingvism.

\footnotetext{
* laşi, Romania;

andreeamanuela@yahoo.com
} 


\section{Introduction}

"One of the most remarkable and challenging ideas for the realization of plurilingual education is the concept of intercomprehension" (Doyé, 2005, p. 7). The concept of intercomprehension is now part of the lexicon of the Didactics of Languages or of the language of those who reflect on teaching and learning foreign languages in the context of promoting the plurilingualism of European citizens. This concept and its didactic implications deserve to be well known in relation to their effects on language learners.

Intercomprehension is one of the current concerns although it has not yet really entered school and university institutions. It is in the state of experience, project or training and yet there is abundant material and intense reflection on this subject. Intercomprehension is considered practical worthy of being tried and for this reason there is a pedagogy and didactics of intercomprehension. After attending in Belgium (Liège) an Education course for teachers of FFL (French as a Foreign Language), I realized that my interest in languages could be exploited in the classroom in a more systematic way than before. Similarly, participating in conferences Partager pour s'enrichir - workshops about integrated didactics and intercomprehension provided by FREPA (a framework of reference for pluralistic approaches to languages and cultures) team members, experts of the European Centre for Modern Languages of the Council of Europe, I decided to test the successes and failures in intercomprehension, based on the implicit and explicit knowledge of the learners.

My objective regarding intercomprehension is to investigate the interest, the possibilities and the modalities of a better awareness of the contact of languages in the classes of French as a foreign language. The approach I have chosen to address this problem consists in trying to transpose into the domain of the Foreign Languages the methods developed in recent years by the didactics of plurilingualism and the didactics of neighbouring languages, in order to stimulate and train students to the concept of intercomprehension in Romance languages.

The aim is to lead pupils towards the promotion of a school culture opened to plurilingualism, to institute comparative habits and to promote awareness of the phenomena of proximity and interlinguistic distance by activities regularly offered in the class of French language. As for the practical part, it is a matter of experimenting the awakening of languages using texts in several languages, while trying to understand the effects that such a work can have on the language skills of pupils. 


\section{Theoretical Aspects}

Europe is linguistically and culturally diverse. The European Union has 28 Member States and 24 official languages. This cultural and linguistic diversity offers many opportunities, but it also involves political problems and complicated practical issues.

Intercomprehension refers to a relationship between languages, a relationship in which speakers of different but related languages can easily understand each other without intentional study or extraordinary effort. It is a form of communication in which each person uses its own language and understands the language of other.

Intercomprehension is a form of multilingual communication, in which people from different linguistic and cultural backgrounds speak their own languages, while understanding each other without the help of an additional language. The idea behind this communicative mode is that people use their receptive language skills more easily, which simplifies understanding and learning a language.

European objectives in language policy are aimed to maintain linguistic diversity and multiculturalism. In light of this, multilingualism is considered the ideal by the EU because it is this diversity that makes Europe what it is: not a melting pot in which differences melt, but a common house that glorifies diversity and where our many mother tongues are a source of wealth and the path to greater solidarity and mutual understanding (Commission des Communautés Européennes, 2005, p. 3).

The field of the concept of intercomprehension has evolved from crosscommunication (each one speaks in its own language and understands those of others) and continues with intrafamilial intercomprehension (developing the skills of written and oral comprehension of the languages of the same family in adult learners), inter-familial intercomprehension (dialogue between language families in terms of geographic and cultural neighbourhoods rather than linguistic) and Language family understanding (approaches are beyond linguistic kinship).

Intercomprehension is a practice of plurilingual comprehension and of interaction competence. This first vision on the concept was developed by Claire Blanche Benveniste (2001) and Louise Dabène (2003) and means the ability to partially understand an oral or written text in an unknown or little known language. This process is based on strategies such as the identification 
of transparent words, analysis and comparison. The ability to interact in a multilingual context with an interlocutor who does not have the same language repertoire, each using his / her reference language, requires an effort to understand the other.

There are a number of language-related languages in Europe from a linguistic point of view. Among these languages are the Romance languages, developed from Vulgar Latin. With more than 430 million speakers, the Romance languages (Spanish, Portuguese, French, Italian, Romanian, etc.), all from Latin, are represented mainly in Europe (Portugal, Spain, France, Italy, Romania) as well as in all of South America, Mexico, part of the United States and Canada.

According to Wikipedia, the Romance languages share a set of common traits that provide remarkable coherence to this language family. The most important among these common traits mentioned are: a lexicon mainly derived from vulgar Latin, a reorganization of the Latin vowel system, important phenomena of palatalization of consonants, the almost complete disappearance of the neutral (with the exception of Romanian), a reorganization important of the verbal system (by the development of auxiliary verbs), the suppression and creation of certain verbal tenses, the development of articles, unknown to Latin.

\section{FFL (French as a Foreign Language) didactics and intercomprehension}

Didactics arose from the construction and development of theoretical models and research methods, with the help of hundreds of researchers gathered in groups of initiative or in associations. This has given rise to profound changes in the educational system, the creation of new curricula, training and more modern means of teaching. The work of the researchers has been transposed into the experimental design, observing, analysing and recording the practices of the class to understand the didactic process. There is a tremendous amount of analytical work that lasts for years and is born of reforms. In Santos (2007, p.3), language didactics gradually moved to the heart of language policies, settling in the field of intervention rather than description. For this reason, there is more work on the application and development of application programs than on the evolution of the concept throughout history.

Researchers promoted multilingual approaches, learning multiple languages and raising awareness for linguistic diversity. Teams of European specialists have carried out projects on these multilingual approaches, based mainly on the families of languages (Latin, Germanic and Slavic, etc.) or on the 
simultaneous learning of foreign languages. Also, at the base of these projects is the Council of Europe's position in developing a European reference framework for teaching, learning and evaluation of modern languages.

\section{Intercomprehension in the class of FFL (French as a foreign language)}

Intercomprehension is a class practice still very rare. The causes are not difficult to explain, they have roots in the professional conceptions of teachers. Their majority do not accept the idea of acquiring partial skills as the purpose of language teaching because they have long developed the taste for normative perfection and now they cannot accept the approximation as an intermediate phase of learning.

Yet, even if the reserves of the majority remain unavoidable, Doina Spi ă (2016) states clearly in a paper work: intercomprehension in language classes is possible! Her conclusion is that intercomprehension manifests an initiatory virtue and that the mixture of pleasure and know-how makes one want to discover languages and then learn them by deepening. This exercise leads to an extremely stimulating feeling of "happiness", inseparable from any success, its virtue of encouragement, confidence building and dynamism being an essential factor of motivation, a real engine of success in learning.

In his reference study Intercomprehension. A Guide for the Development of Education Policies in Europe - From Linguistic Diversity to Plurilingual Education (2005), Peter Doyé asks himself the question of the prospects and the chances of success of intercomprehension. Concerning this problem, it identifies some factors influencing the field and the level of understanding: the proximity of the languages involved the level of training of the learners, their verbal intelligence and also their motivation. On the proposal for a possible integration of inter-comprehension in school curricula, Peter Doyé sees two possibilities: the first is the integration of the intercomprehensive principle in the existing language courses at school, in a teaching accompaniment traditional language, in the sense that the acquisition of one language serves as an example for learning other languages. The second option is to teach intercomprehension as an independent discipline through curriculum design.

On the teaching of a language for allophones, Pierre Escudé and Pierre Janin (2010) argue that the FFL (French as a Foreign Language) is based on the integration of two languages: the source language of the learner, one or multiple, and target language, French. They also talk about three levels of involvement in inter-comprehension in the school environment: awareness, initiation and learning. 
At the "loanid Romanescu" School from Voineşti (laşi county), I have already made the first steps: I have gone through the awareness-raising stage and halfway through the initiation stage with the Romance Itineraries activities. Classroom activities were built on the existing language knowledge of pupils and trained them regularly (twice a month) to tap into their language resources, through didactic situations in everyday school activities that focus on observation and the comparison between different languages.

From this attempt resulted that the pupils are aware of a European belonging, the fluidity of circulation in languages. Once the eyes, hearing and observation of the students are trained, they become more aware of the particularities of each language and can rely on what they know in a language to better understand another one, taking advantage of a synergy between the different language learning. Any teacher can make her pupils aware of linguistic diversity on condition that she is sensitive herself on her own language course and on her relationship to languages. It is not necessary to be a specialist in the languages that you propose, it is only necessary to identify and recognize the linguistic resources of the pupils to arouse their curiosity, because the intercomprehensive approach works as a strategy of awareness. It aims to transform the unconscious knowledge of the learner into conscious knowledge.

\section{Intercomprehension in class: methodological leads}

In order to implement intercomprehension activities based on written documents, it is better to choose languages that belong to the same family as the language of the learner. It is also advisable to approach the languages closest to those of the learner, according to the interests displayed, the linguistic profile observed or the geographical proximity of the language.

The basic intercomprehension activities focus on understanding written documents in different languages and one can propose versions of the same text in several languages (a tale, a poetry, a text that already exists in several languages or that we can translate ourselves: Little Red Riding Hood, Little Prince, etc.) We can also select different documents written in different languages but having the same theme (holidays, leisure and sports). It is also possible to offer documents composed of sequences written in different languages (cooking recipes, announcements, multilingual dialogues) and to vary the languages also used to design the instructions or the evaluation.

Some general criteria must be met in the choice of texts, like the adaptation of the text to the public and choosing texts that are understandable and attractive and motivating: stories of adventure, comics, stories, myths, music, etc. Another important point in the choice of a material must be the presence 
of illustrations, photos, drawings, diagrams, time tables, to capture the attention of the learner and guide him in the task of understanding. To help the learner, we can translate the opaque lexicon; we can verbalize the texts and also alternate the type of questions (multiple choices), using the ICT (Information and Communication Technology) resources, to which the young audience is very reactive.

Oral intercomprehension activities are more limited in some aspects, because speaking does not allow the learner to grasp the entire message at a glance. Also, the analysis of a sound or audio-visual document requires a great effort of memorization because most often it is impossible to slow down the (speaking) flow. Choosing a sound document to work in class proves to be much more delicate than the choice of writing. We must ensure the sound quality of the recording; we must evaluate the quality of the speakers' oral expression, choosing a sufficient volume of voice, a moderate flow and a good articulation of the speakers.

The audio-visual document must be chosen with priority because the audiovisual offers many more clues to the learner. It is necessary to warn the learner not to block on the excluded segments and to have realistic expectations on the understanding of the message, orienting the student towards a work of global comprehension of the document.

Oral documents must be chosen according to the public: young people (cartoons, nursery rhymes, stories, recipes explained) or teenagers (music, weather report, answering machine, video game, report, etc.). The task of the learner should be directed by asking traditional questions: who is speaking and to whom, what is the subject, what is the purpose of the conversation, etc.

Audio-visual allows working all the indices of meaning offered by the image. These indices encourage the learner to observe the images, the movements of the speakers, their actions and reactions, the objects indices, etc. with discernment.

For the textual content of the sound document, words and transparent grammatical structures continue to represent fundamental anchors for understanding. Identification difficulties arise in the case of congeners, because of segmentation problems, consonant loss during the evolution of certain languages, etc.

To optimize the chances of understanding oral documents, in a high level of difficulty, preparatory exercises are essential to avoid errors in the segmentation 
of the sound flow. There is a need for risk training, syllabic cutting and exercises with facilitator recordings that gradually familiarize the learner with the sounds of the target language, through linguistic affinities.

During the 2016-2017 school years I tested the success of integrating intercomprehension into the FFL (French as a Foreign Language) classroom. To introduce this concept into teaching, I opted for an out-of-school course with sixth graders, through an extra-curricular activity of one hour, twice a month. The purpose of this experiment was to observe the premises of a possible curriculum insertion with middle school students.

I used the existing activity on the Latin Union site, The Treasure of the Isle of Salvation, module 1 of the online Romance Routes tutorial, a fun tool that promotes intercomprehension in Romance languages. Available online, this tutorial includes six modules that work independently, providing integrated activities in six Romance languages (Catalan, Spanish, French, Italian, Portuguese and Romanian) and is intended for an audience of 9 to 13 years, can be perfectly exploited in school structures. These modules facilitate the simultaneous work of the six languages, the learner grasping the multilingualism and the functioning of other linguistic systems.

The six modules of the series - Le trésor de l'île du Salut (The treasure from the island of salvation); Le Chat botté (Puss in Boots); La véritable et sympathique histoire de la pizza Margherita (The real and friendly story of the pizza Margherita); Le long voyage de Tomi (Tom's long journey); La princesse, le baobab et les cauris (The princess, the baobab and the cowries) and Voix sans frontières (Voices without borders) - and have to entertain, to motivate the learners with the help of a story, illustrated in the style of a comic book. These modules also facilitate the identification of Romance languages, both written and oral, by setting up strategies for the perception and identification of some basic speech acts. They give the taste to continue learning a second, third or even fourth language by focusing on taking into account the proximity of the languages offered. Each module is planned with an internal evaluation of the results obtained, in the form of a personalized diploma for the accomplishment of the tasks, which helps and motivates the pupils.

The interactive interface, the attractive sound, the novelty of the work immediately aroused the interest of my students who immediately wanted to work this module on the computer, in a team or individually. They had the freedom to choose the language in which to complete the exercises. They confessed that after the session, at home, they also worked the other existing modules on the platform. 
During these work sessions, I made several observations: the students were surprised by their own ability to access the meaning of the words of another Romance language, unknown or little known to them. After each session, we analysed the problematic situations and the strategies that were initiated to complete the task. Some of them have observed the logical sequence of language teaching, the transfer which can be used in the intercomprehensive context where languages are bridges for each other. They have developed a capacity for critical analysis, because they have reflected on the similarities, difficulties and results of these incursions into intercomprehension. Gradually, they developed a confidence, a learning autonomy and they began to believe in their abilities.

They were also surprised by the fact that I, as a teacher, was in the same state of discovery as them, that I did not know all the answers, that we solved problems together, all in position of learning, discovering together how to mobilize the resources available in our memories.

They also discovered the pleasure of playing with the function of online translation tools, with the help of which translated words and phrases are converted to audio format, allowing students to hear the exact pronunciation of the words they are looking for.

We arrived together at the conclusion that any linguistic knowledge can become source of knowledge: the language spoken by a neighbour or a cousin, the language spoken by a family member, the text of a song, the menu of a game video, any occasion can be used.

These sessions had multiple effects on the students and also on me, as a teacher. I went through a process of synthesis to consider the teaching of languages in a plural way, I developed a didactic consciousness and I reflected on the implications of the curricular insertion of intercomprehension.

Apart from these sessions, I introduced the intercomprehension in my regular classes, always using transparent words from other Romance languages that I had access to through my own history of formation.

The introduction of intercomprehension in language teaching highlights the fact that languages do not exist in isolation, but there are links between them that facilitate language learning. Today's task of the teacher is to make students aware of this plural knowledge and allow them to use it by developing appropriate strategies. 


\section{Curriculum insertion proposal for intercomprehension}

Intercomprehension is becoming more and more common as a method of teaching languages. In language learning it invites to guess, to discover trends, to decode and to anticipate. Knowledge of other languages helps, but also general, cultural, situational and behavioural knowledge. In intercomprehension, all kinds of prior knowledge are used to make deductions, which helps in the comprehension or partial comprehension. Research shows that it is easier to learn a language from the same language family.

The phenomenon of intercomprehension has been born naturally and intuitively inserted into my pedagogical reflection for a long time, but it took years to discover that the lexical resonances I have noticed, the transparency that I have observed and used often during my classes and the use of knowledge in various languages had a name and didactics.

The decision to integrate intercomprehension in the classroom has roots in my own vocational training and personal life, as I have always been attracted to languages, flirting with Spanish courses and conversations in Italian, benefiting from of various occasions of this intercomprehensive magic.

Students are generally open to new things, they like changes in perspective and marvel when they perceive knowledge that they were unaware of. They received with surprise my intercomprehensive propositions and now they wish to repeat the experiment as often as possible.

I have always had a musical ear for words and I have made pupils and even friends aware of what today is called intercomprehension, without knowing its name. Now I have the legal framework to become more than the one language professor (French Teacher) but the language(s) teacher, to methodologically and intuitively try this new strategy using existing tools.

As a result of this work on intercomprehension, I have come to the conclusion that curricular insertion is possible in the school where I teach, based on the most recent national and European recommendations and especially the REFIC (Référentiel de compétences de communication en intercompréhension) guidelines. Through the Intercomprehension module At the crossroads of languages, the learner is confronted with several languages, which he does not necessarily need to know, but that I can ask him to learn to recognize starting with reflections and comparisons. 
The insertion of intercomprehension is going to be done during the stage of awakening to languages, in an active discovery, oral and written, of several languages (which are not taught explicitly at school) that I choose among the languages already present in the curricula, wanted by the school or desired by the pupils themselves, inviting them to reflect on the sound, the written codes, their symbols or their uses.

Through this process of curriculum insertion, I want to continue the awareness step with a training step, to put in place a pluralistic education for languages and cultures, in order to concretely realize in the daily didactic activity the development of plurilingual and intercultural competence, advised by the European language and education policy.

There are many sources to exploit and to implement in class, for practicing intercomprehension between parent languages. The Miriadi site and the European Centre for Modern Languages (ECML) offered me suggestions for developing and personalizing this proposal. Using the examples offered by FREPA (A framework of reference for pluralistic approaches to languages and cultures) and the REFIC (Référentiel de compétences de communication en intercompréhension), I was able to build my own functional teaching path for one school year, one hour a week.

I want to try to introduce this obvious concept into the school system and allow the development of a language intercomprehension program; because I believe that its inclusion in curricula is a fundamental prerequisite and a necessity. The next step is to propose an Erasmus + project on this subject and eTwinning projects.

\section{Conclusions}

Intercomprehension did not wait for its conceptualization to exist. As a tool for dialogue and international integration, plurilingualism is now promoted by many countries through education and training, encouraging partnerships for transnational mobility and encouraging participants to learn languages. Established contacts become more direct through the mediation of information resources and modern language technologies.

While the theory of intercomprehension is already well studied, its practice evolves in small circles because implementation implies changes in curriculum development and teacher training. The specificities of each country and its pace of work must be taken into account. 
Intercomprehension is entered on a path that does not have a return way. At a global level, it is also observed that intercomprehension is taken into account as a universal value.

I feel that I can make a difference in my school for my pupils, taking into account the intercultural dimension of learning through an intercomprehensive and plurilingual pedagogical approach. I started from the hypothesis that an experimentation of awakening to the languages can lead to the intercomprehension, while being an important asset for the learning of the language. That's why I decided to offer an optional course entitled At the Crossroads of Languages. The implementation of a multilingual curriculum does not only require diversification but also internal work of evolution and adaptation of oneself. You cannot do everything but you can try to do a little bit of everything.

This intercomprehensive approach is the best personal pedagogical discovery I could make because it is the only one that fuses with my passion for languages and the pleasure of juggling them. Intercomprehension is simply a fact of life, becoming rather a rule than the exception. It is useful for speakers because it allows both parties to use the language they know best. However, it should be stressed that intercomprehension depends entirely on the goodwill of the speakers of the different languages to understand each other.

Studying intercomprehension can be very helpful in stimulating linguistic horizons and developing metacognitive strategies that can be applied to any language. Moreover, as Blanche Benveniste has already pointed out, this innovative way of looking at languages can stimulate learners to reflect on their own mother tongue at a deeper level. Understanding being the first step in language learning, multilingual approaches can help the learner of a related language overcome the barriers of a new language learned.

From my personal experience with intercomprehension, I can say that my attitude towards foreign languages is more open than before and that the list of languages I want to learn is getting bigger and bigger. Thanks to scholarships in France and Belgium, I was able to meet people from all countries and I was able to put into practice the intuitive strategies of this magical dialogue.

With regard to the introduction of plurilingual education in Romanian schools, I believe that there are some challenges to achieving them successfully: costs, the opening of professors to other languages they do not master, the gaps between the amount of work and the teacher's time and also the place of intercomprehension within the framework of the recognized evaluations. But 
all this does not represent an insurmountable obstacle, since the evolution towards the integration of intercomprehension is inevitable.

\section{REFERENCES}

Blanche-Benveniste, C. (2001). Nouveaux apports de la grammaire contrastive des langues romanes. Uzcanga Vivar, Isabel, 4154.

Carrasco Perea, E. (2010). Intercompréhension (s): repères, interrogations et perspectives. Synergies Europe, 5, 7-12.

Commission des Communautés Européennes. (2005, November 22). Un nouveau cadre stratégique pour le multilinguisme: communication de la Commission au Conseil, au Parlement européen, au Comité économique et social européen et au Comité des régions. Retrieved from http://eur-lex.europa.eu/legal-content/FR/TXT/PDF/?uri=CELEX: 52005DC0596\&from=FR.

Dabène, L. (2003). De Galatea à Galanet. Un itinéraire de recherche. Lidil. Revue de linguistique et de didactique des langues, (28), 2329.

Doyé, P. (2005). L'intercompréhension. Guide pour l'élaboration des politiques linguistiques éducatives en Europe. De la diversité linguistique à l'éducation plurilingue. Étude de référence. Étude de Référence, Division Des Politiques Linguistiques, Conseil de l'Europe Strasbourg.

Escudé, P. \& Janin, P. (2010). Le point sur l'intercompréhension, clé du plurilinguisme. Paris: CLE International.

http://pedagogie.ac-toulouse.fr/langues-vivantes/spip209/

IMG/pdf/_intercomprehension_clef_du_plurilinguisme_-_ cle_international_-_paris_2010_copy.pdf.

Fédération internationale des professeurs de français. (2016, September 19). Résolutions du Congrès de Liège. Retrieved from http://fipf.org/sites/fipf.org/files/resolutions_liege.pdf.

Melo, S., \& Santos, L. (2007). Intercompréhension (s): les multiples déclinaisons d'un concept. Diálogos Em Intercompreensão: Actas Do Colóquio. Lisboa: Universidade Católica Portuguesa.

Spi ă, D. (2016). Compte-rendu d'expérience: l'intercompréhension en classe de langues, c'est bien possible! Le Français à l'université. Retrieved from http://www.bulletin.auf.org/index.php?id=2310\#quotation.

Tonnar, C., Krier, M., \& Perregaux, C. (2010). Ouverture aux langues à l'école: vers des compétences plurilingues et pluriculturelles. MENFP.

*** Association pour la promotion de l'intercomprehension des langues. Retrieved from http://apic.onlc.fr/16-Accueil-Agenda.html. 
The online version of this article can be found at: http://revped.ise.ro/category/2017-en/$$
\text { (C) (1) }
$$

This work is licensed under the Creative Commons Attribution-NonCommercialShareAlike 4.0 International License.

To view a copy of this license, visit http://creativecommons.org/licenses/by-ncsa/4.0/ or send a letter to Creative Commons, PO Box 1866, Mountain View, CA 94042,
Versiunea online a acestui articol poate fi găsită la: http://revped.ise.ro/category/2017-ro/

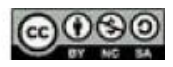

Această operă este pusă la dispozi ie sub licen a Creative Commons AttributionNonCommercial-ShareAlike 4.0 International.

Pentru a vedea o copie a acestei licen e, vizita $i$ http://creativecommons.org/licenses/by-ncsa/4.0/ sau trimite i o scrisoare către Creative Commons, PO Box 1866, Mountain View, USA. CA 94042, SUA. 